\title{
Penalaran Siswa SMA dalam Menyelesaikan Soal Non-Routine
}

\author{
Fahrun Nisa' ${ }^{1}$, I Made Sulandra ${ }^{1}$, Abadyo $^{1}$ \\ ${ }^{1}$ Pendidikan Matematika-Universitas Negeri Malang
}

\begin{tabular}{l} 
INFO ARTIKEL \\
\hline Riwayat Artikel: \\
Diterima: $13-05-2019$ \\
Disetujui: $17-11-2019$ \\
\hline
\end{tabular}

Kata kunci:

reasoning; reasoning indicators; non-routine question penalaran; indikator penalaran; soal non-routine

\begin{abstract}
ABSTRAK
Abstract: The purpose of this study is to describe students' reasoning in solving nonroutine problems. This study uses descriptive exploratory research with a qualitative approach. This research was conducted on 33 MIPA SMA Laboratory UM students. A subject is taken based on student answers that are complete, correct, from the teacher's recommendations and the results of the analysis that meet five reasoning indicators, namely analysis, synthesis, generalization, justification and resolution of non-routine problems. The results of this study state that the more dominant subject performs the analysis by explaining information, doing the right calculation; then do the synthesis by combining information; generalize by identifying forms; justify by giving reasons as well; solve non-routine problems.

Abstrak: Tujuan penelitian ini adalah untuk mendeskripsikan penalaran siswa dalam menyelesaikan soal non-routine. Penelitian ini menggunakan penelitian deskriptif eksploratif dengan pendekatan kualitatif. Penelitian ini dilakukan kepada 33 siswa MIPA SMA Laboratorium UM. Seorang subjek diambil berdasarkan jawaban siswa yang tuntas, benar, dari rekomendasi guru serta hasil analisis yang memenuhi lima indikator penalaran, yaitu analisis, sintesis, generalisasi, justifikasi, dan penyelesaian masalah non-routine. Hasil penelitian ini menyatakan bahwa subjek lebih dominan melakukan analisis dengan menjelaskan informasi, melakukan perhitungan yang benar; kemudian melakukan sintesis dengan menggabungkan informasi; melakukan generalisasi dengan mengidentifikasi bentuk; melakukan justifikasi dengan memberikan alasan; menyelesaikan soal non-routine.
\end{abstract}

\author{
Alamat Korespondensi: \\ Fahrun Nisa' \\ Pendidikan Matematika \\ Universitas Negeri Malang \\ Jalan Semarang 5 Malang \\ E-mail: fahrunnisa33@gmail.com
}

Penalaran adalah salah satu komponen penting dalam belajar matematika. NCTM (2000) mengatakan bahwa kemampuan penalaran merupakan hal yang sangat penting untuk memahami matematika. Selain itu, NCTM (2000) juga menyatakan bahwa penalaran sebagai sarana penting dalam pembelajaran serta menyajikan makna yang penting dalam mengembangkan ide. Terdapat beberapa pengertian tentang penalaran oleh beberapa peneliti. Menurut Webster (1982, dalam Gunhan, 2014) penalaran merupakan kemampuan untuk berpikir secara koheren dan logis, dan juga untuk menarik kesimpulan dari fakta yang diketahui atau diasumsikan. Rizta, dkk. (2013) berpendapat bahwa penalaran adalah proses berpikir dalam menentukan sebuah kesimpulan dari suatu pengetahuan baru yang diterima dengan cara mengaitkan antara pengetahuan baru tersebut dengan pengetahuan yang telah dimiliki sebelumnya. Bergqvist, dkk. (2008) berpendapat bahwa penalaran adalah alur pemikiran atau pola pikir yang diadopsi untuk menghasilkan suatu pernyataan dan mencapai kesimpulan. Dari pendapat beberapa peneliti di atas, dapat dipahami bahwa penalaran merupakan suatu proses atau aktivitas berpikir untuk menarik kesimpulan atau menghasilkan suatu pernyataan baru secara logis dan benar berdasarkan fakta/informasi yang diketahui atau diasumsikan serta sumber yang relevan. Namun demikian, seorang peneliti bernama Lithner (2012) mengungkapkan bahwa penalaran itu tidak selalu didasarkan pada logika formal, tidak terbatas pada pembuktiannya bahkan mungkin saja penalarannya salah walaupun terdapat beberapa alasan logis yang mendukungnya.

Pembelajaran matematika di sekolah erat kaitannya dengan penalaran. Sebagaimana yang tertuang pada tujuan pembelajaran matematika dalam standar isi Kurikulum 2013 untuk siswa SMA pada kompetensi keterampilan, yaitu terdapat kegiatan mengolah, menalar, dan menyaji dalam ranah konkret dan abstrak terkait pengembangan diri yang dipelajari di sekolah. Hal ini diperkuat dengan salah satu standar proses yang harus ada dalam pembelajaran matematika yaitu penalaran (NCTM, 2000). Untuk meningkatkan kemampuan penalaran matematika, siswa harus mengembangkan dan meningkatkan kemampuan penalarannya (Adegoke, 2013). Hal ini dikarenakan ketika siswa dihadapkan dengan masalah maka ia akan 
menggunakan keterampilan penalarannya untuk menyelesaikan masalah tersebut dan mendapatkan solusi serta alasan yang logis (Brodie, 2010 dan Berqvist, dkk., 2008).

Secara umum, soal atau masalah adalah masalah rutin apabila dapat diselesaikan baik dengan mengganti data tertentu menjadi masalah umum yang diselesaikan secara formal atau dengan mengikuti contoh langkah demi langkah yang dicontohkan (Lee \& Chen, 2009). Banyak penelitian yang menyarankan bahwa siswa harus didorong untuk mengerjakan tugas pemecahan masalah soal non-routine. Hal ini dimaksudkan untuk membantu siswa melihat makna dan relevansi dari apa yang mereka pelajari serta untuk memfasilitasi pengetahuan kontekstual mereka (Lee \& Chen, 2009). Sependapat dengan hal ini, Jonassen (1997, 1999 dalam Lee \& Chen, 2009) menyatakan bahwa apabila siswa menyelesaikan soal non-routine maka siswa diharuskan untuk menggunakan keterampilan penalaran tingkat tinggi. Masalah non-routine dianggap lebih rumit dan sulit daripada masalah rutin dimana hanya penerapan perhitungan rutin yang terlibat dalam solusi mereka (Pantziara, dkk. 2009). Elia, dkk. (2009) mendefinisikan masalah non-routine sebagai masalah yang tidak memiliki solusi langsung, tetapi membutuhkan pemikiran kreatif dan menggunakan strategi tertentu. Soal non-routine merupakan soal yang belum dikenal oleh siswa, artinya siswa tidak mengetahui solusi penyelesaiannya (Carlson \& Bloom, 2005). Dengan demikian, definisi dari soal non-routine yaitu soal yang tidak dapat diselesaikan menggunakan prosedur yang sudah dikenal atau yang rutin digunakan.

Untuk mengukur penalaran siswa, peneliti menggunakan indikator yang digunakan oleh TIMSS (Mullis, 2012) yang sudah dimodifikasi oleh Gunham (2014) yang meliputi analisis, sintesis/integrasi, generalisasi, justifikasi, dan pemecahan masalah non-routine. Dalam jurnalnya, dijelaskan pengertian tentang masing-masing indikator yang telah peneliti sesuaikan dengan tema pada penelitian ini. Pertama analisis yaitu mengidentifikasi dan menggunakan keterhubungan antara variabel di dalam situasi matematika. Kedua sintesis/integrasi yaitu menggunakan operasi matematika dalam kombinasi dan menggabungkan hasil yang didapatkan untuk mendapatkan solusi yang benar. Ketiga genaralisasi yaitu berpikir secara matematika dan menjelaskan hasil yang diperoleh melalui pemecahan masalah dan menggeneralisasi hasil tersebut. Keempat justifikasi yaitu menggunakan hasil atau properti matematika untuk memberikan bukti dalam kebenaran tindakan atau keyakinan ekspresi matematika. Kelima adalah pemecahan masalah non-routine, yaitu menyelesaikan soal non-routine dengan menerapkan pengetahuan materi yang sudah didapatkannya serta menggunakan proses matematika yang sesuai. Kelima indikator ini digunakan untuk melihat lebih dalam proses penalaran siswa.

Untuk lebih memahami kelima indikator penalaran, berikut disebutkan sub indikator dari masing-masing indikator (1) analisis; menuliskan informasi apa saja yang diketahui, menjelaskan ide-ide matematika, mengidentifikasi variabel yang ada pada soal, menuliskan model matematika, menuliskan perhitungan matematika dengan benar serta mendeduksi hasil yang tepat dan benar berdasarkan informasi yang ada pada soal (2) sintesis/justifikasi; menggabungkan informasi yang diketahui, menggabungkan prosedur matematika yang telah diketahui, (3) generalisasi; membuat dugaan penyelesaian, mengidentifikasi bentuk matematika, (4) justifikasi; memberikan alasan atau bukti untuk mendukung strategi dan solusi penyelesaian, (5) penyelesaian masalah non-routine; menggunakan strategi penyelesaian yang tepat, menyelesaikan masalah dengan prosedur yang benar, menggunakan pengetahuan matematika yang dimiliki sebelumnya untuk pemecahan masalah non-routine.

Kelima indikator di atas akan digunakan untuk menyelidiki keterampilan penalaran siswa dalam menyelesaikan soal non-routine. Hasil penelitian ini sangat penting untuk menilai cara siswa berpikir saat memecahkan masalah non-routine dan juga untuk mengamati cara mereka menunjukkan keterampilan penalaran. Selain itu, penelitian ini akan membantu guru untuk menilai apakah kinerja siswa mencerminkan keterampilan penalaran mereka sehingga guru dapat mempertimbangkan metode pembelajaran yang sesuai.

\section{METODE}

Penelitian ini menggunakan pendekatan deskriptif eksploratif, yaitu penelitian dengan tujuan untuk mengeksplorasi keterampilan penalaran siswa dalam menyelesaikan soal non-routine kemudian dideskripsikan berdasarkan lima indikator penalaran yaitu analisis, sintesis, generalisasi, justifikasi dan pemecahan masalah non-routine. Seorang subjek dipilih dari 33 siswa kelas 10 MIPA II berdasarkan jawaban test soal non-routine yang tuntas dan benar. Selain itu, pemilihan subjek juga berdasarkan rekomendasi dari guru mata pelajaran untuk siswa yang mempunyai kemampuan matematika yang tinggi serta kemampuan komunikasi yang baik. Setelah itu subjek diberikan pertanyaan dalam proses wawancara dengan tujuan agar kemampuan penalaran siswa lebih terlihat. Hasil wawancara akan dianalisis berdasarkan kelima indikator penalaran.

Soal instrumen merupakan soal non-routine yang diadopsi dari Booker (2009). Untuk alur penelitiannya diawali dengan pemberian soal tes non-routine kemudian jawaban tes dan hasil wawancara dianalisis berdasarkan kelima indikator penalaran Hasil analisis merupakan data penelitian yang telah direduksi sesuai tema penelitian. Setelah data terkumpul, peneliti melakukan analisis terhadap data yang diperoleh berdasarkan kelima indikator penalaran yang digunakan dalam penelitian ini.

\section{HASIL}

Hasil yang dipaparkan merupakan deskripsi penalaran siswa dalam menyelesaikan soal non-routine. Berikut merupakan soal test non-routine yang diadopsi dari Booker (2009) dan telah dikembangkan berdasarkan indikator penalaran. 


\section{Cerita Tarik Tambang}

Pada perlombaan tarik tambang, lima ekor lembu sama kuat dengan delapanekorkeledai.

2......

Seekor gajah sama kuat dengan seekor lembu dan empat ekor keledai.

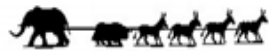

Berdasarkan ilustrasi yang diberikan di atas, jawablah pertanyaan dibawah ini:

1. Siapakahyang akan memenangkan tarik tambang ini, jika seekor gajah dan empat ekor keledai melawan lima ekor lembu?

\section{2tabo}

2. Untukngajah, tentukan:

a. Berapakah banyakkeledai yang dapat melawangajah agar permainan berakhir seimbang atau samakuat?

b. Berapakah paling banyak keledai yang dibutuhkanuntuk melawangajahagar gajahmenang?

c. Berapakah paling sedikit keledaiyang dibutuhkanuntuk melawangajahagar gajahkalah?

\section{Gambar 1. Soal Test Penalaran}

Deskripsi Penalaran Subjek (S)

Subjek merupakan siswa yang mempunyai kemampuan matematika yang tinggi dan capaian hasil belajarnya bagus menurut guru pengampu. Berikut merupakan paparan data hasil dari jawaban subjek.

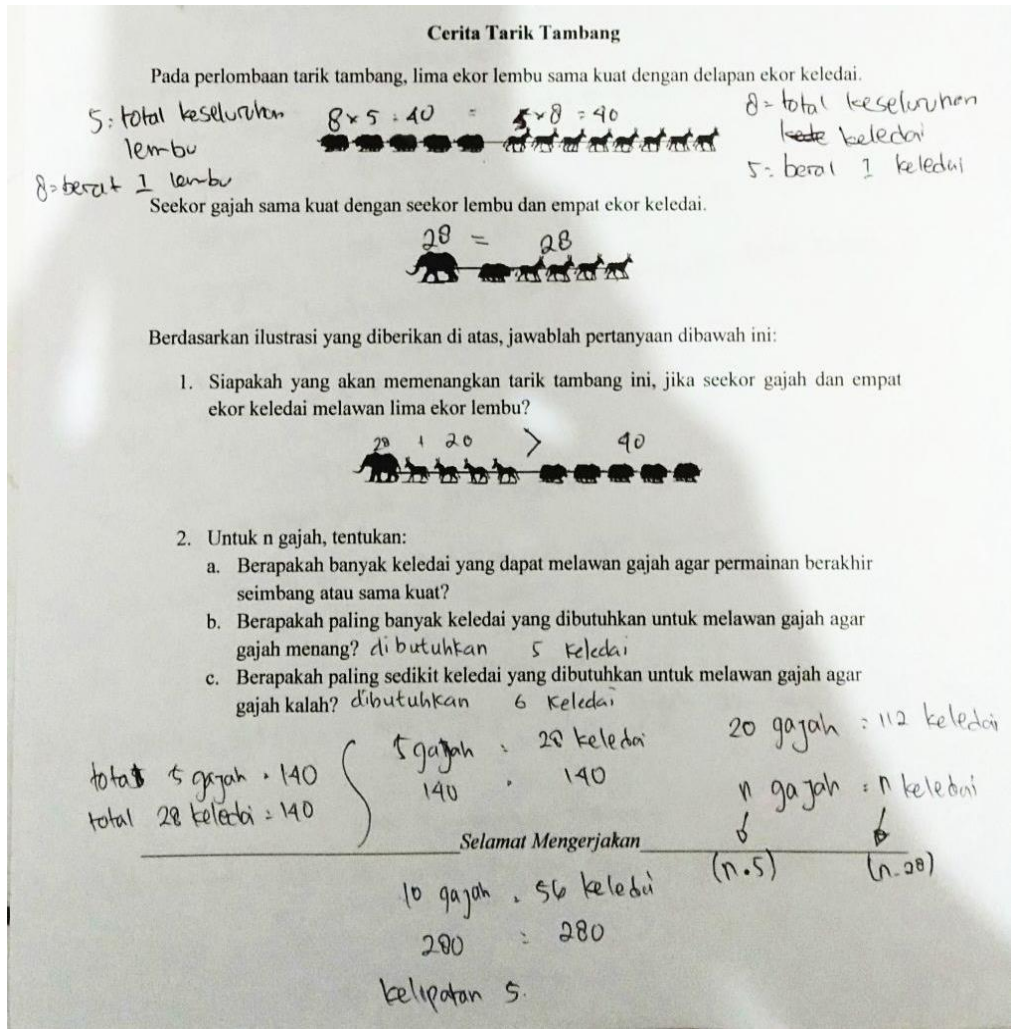

Gambar 2. Jawaban Test Subjek 
Ketika mencari nilai dari persamaan pertama, S mencari kelipatan persekutuan terkecil (KPK) dari kedua kubu dimana pembatas kedua kubu ditandai dengan tali terpanjang. Pada persamaan pertama ini, kubu kiri mempunyai lima ekor lembu, sedangkan kubu kanan mempunyai anggota delapan ekor keledai sehingga KPK dari persamaan pertama yaitu 40. Selanjutnya, $\mathrm{S}$ menghitung nilai dari masing-masing hewan pada tiap kubu. Pada gambar, hewan yang sama jenisnya memiliki ukuran yang sama besar, sehingga S mengasumsikan semua lembu kekuatannya sama, begitu pula dengan keledai. Untuk seekor lembu, S memberikan nilai 8 yang diasumsikan sebagai berat atau kekuatan yang dimiliki seekor lembu adalah 8 , sedangkan untuk seekor keledai nilainya 5, yang artinya berat atau kekuatan keledai adalah 5. Dalam hal ini $\mathrm{S}$ melakukan analisis berupa menuliskan ide-ide matematika yaitu memberi tanda = untuk berat dari kedua kubu, dan melakukan perhitungan yang tepat. Hal ini juga diperjelas dari potongan wawancara berikut:

P : Ceritakan bagaimana kamu mendapatkan nilai dari masing-masing hewan.

$\mathrm{S}$ : Diketahui total keseluruhan lembu 5 jadi berat 1 lembu 8, sedangkan total keseluruhan keledai ada 8 maka berat 1 keledai 5 .

$\mathrm{P}$ : Dapat darimana berat 1 lembu 8 dan berat 1 keledai 5 ?

S : Karena KPK nya 8 dan 5 itu 40. Kan lembu jumlahnya 8 sedangkan keledai jumlahnya 5, lalu dicari KPK dari 8 dan 5 ketemu 40, maka masing-masing hewan dibagi 40 dan ketemu per 1 lembu beratnya 8 dan per 1 keledai beratnya 5.

Dari cuplikan wawancara di atas dapat dilihat bahwa S melakukan analisis dengan menjelaskan informasi apa saja yang diperoleh dari soal. Selain itu S juga melakukan penyelesaian masalah non-routine dengan menggunakan pengetahuan matematika yang dimiliki sebelumnya untuk mencari berat dari masing-masing hewan untuk kedua kubu. Hal itu ditandai dengan mencari KPK dari lembu dan keledai. S juga melakukan justifikasi dengan memberikan alasan dari setiap cara yang diambil. Akan tetapi, S masih salah dalam memaknai nilai hewan, S hanya mengatakan nilai itu sama dengan berat, S juga tidak memisalkan hewan menjadi variabel serta pemaknaan nilai yang dijelaskan S kurang tepat.

Selanjutnya ketika mencari nilai dari persamaan kedua, $\mathrm{S}$ melakukan metode substitusi nilai yang telah didapat di persamaan pertama untuk mendapatkan nilai dari seekor gajah yang terdapat di kubu kiri. S mengganti lembu dengan nilai 8 dan mengganti keledai dengan nilai 5, karena terdapat empat keledai, maka S mengalikan empat keledai dikali lima yaitu nilai per seekor keledai sama dengan 20 karena kubu kanan ada seekor lembu dan empat ekor keledai, maka semua dijumlahkan dan hasilnya 28 sehingga nilai dari seekor gajah sama dengan 28. Dalam hal ini S melakukan analisis dengan mendeduksi hasil yang tepat dan benar berdasarkan informasi yang ada pada soal serta melakukan perhitungan matematika yang benar. Selain itu, S juga melakukan sintesis dengan menggabungkan informasi yang diketahui dari persamaan sebelumnya. Hal ini didukung dengan cuplikan wawancara dibawah ini.

P : Ceritakan bagaimana kamu mendapatkan nilai dari persamaan kedua.

$\mathrm{S}$ : Tinggal dimasukin aja nilai dari lembu dan keledai maka ketemu nilai nya gajah.

P : Jadi berapa nilai gajah?

$\mathrm{S}: 28$

P : Kok bisa 28 ? Bagaimana penjelasannya?

$\mathrm{S}$ : Tadi kan 1 lembu nilainya 8 lalu 1 keledai nilainya 5, di persamaan kedua ini seekor gajah sama dengan seekor lembu dan 4 ekor keledai, jadi lembunya 5 ditambah keledainya 8 karena ada 4 keledai maka $4 x 8=28$, maka gajahnya sama dengan 28 .

$P: 28$ itu apanya?

S : Beratnya. Satu gajah beratnya 28.

$\mathrm{P}: 28$ saja? Atau 28 apa?

$\mathrm{S}$ : entah 28 kilo atau apa, yang jelas berat satu gajah adalah 28.

Dari cuplikan wawancara di atas, terlihat bahwa $\mathrm{S}$ melakukan analisis dengan menjelaskan informasi yang ada di soal. Selain itu, S juga melakukan sintesis dengan menggabungkan informasi yang diketahui dari persamaaan pertama. S juga melakukan pemecahan masalah non-routine dengan menggunakan pengetahuan matematika yang dimiliki serta menggunakan strategi penyelesaian yang benar, yaitu menggunakan metode substitusi untuk mencari berat dari gajah. S juga melakukan justifikasi dengan memberikan alasan mengapa mengambil metode tersebut.

Setelah S memberikan penjelasan untuk kedua persamaan di atas, peneliti melanjutkan pada poin yang ditanyakan. Untuk soal nomor 1, S kembali menggunakan metode substitusi untuk menjawab. S mengatakan bahwa untuk kubu kanan karena terdapat lima ekor lembu dan berdasarkan persamaan pertama seekor lembu nilainya 8 maka $5 \times 8=40$, sedangkan untuk kubu kiri yang terdiri dari seekor gajah dan empat ekor keledai akan dihitung sebagai berikut: berdasarkan persamaan kedua, seekor gajah nilainya 28, sedangkan seekor keledai nilainya 5, karena terdapat 4 ekor keledai maka 4x5=20, sehingga semua dijumlahkan dan hasilnya 48. Karena berdasarkan perhitungan kubu kiri nilainya 48 sedangkan kubu kanan nilainya 40, maka yang memenangkan permainan adalah kubu kiri yaitu seekor gajah dan 4 ekor keledai. Dalam hal ini, $\mathrm{S}$ melakukan analisis dengan menuliskan informasi dari soal. Selain itu, S juga melakukan penyelesaian masalah non-routine dengan menggunakan 
pengetahuan matematika yang dimiliki sebelumnya. Selanjutnya, S juga melakukan sintesis menggabungkan informasi sebelunya yang ada di soal. Hal ini diperkuat dengan cuplikan wawancara berikut:

$\mathrm{P}$ : pertanyaan nomor 1, apa yang kamu tangkap dari soal?

$\mathrm{S}$ : ada dua kelompok hewan trus siapa yang menang taik tambang. Ya tinggal masukin nilainya bu, jadi yang menang adalah gajah dan 4 keledai, kubu kiri

$\mathrm{P}$ : mengapa demikian? Gimana penjelasannya?

$\mathrm{S}$ : kan gajah nilainya 28 lalu ditambah 4 keledai $(4 \times 5=20)$ hasilnya 48 sedangkan kubu kanan ada 5 lembu, kan tadi 1 lembu beratnya 8 jadi $5 \times 8=40$ maka ketemu kubu kiri yang lebih berat jadi menang yang kiri.

$\mathrm{P}$ : itu tanda apa yang digambarmu?

$\mathrm{S}$ : tanda lebih dari bu, karena menang 1 gajah dan 4 keledai maka kubu kiri lebih dari kubu kanan yaitu 5 lembu.

Dari wawancara di atas, terlihat bahwa S melakukan analisis dengan melakukan perhitungan dengan benar. S juga melakukan sintesis dengan menggabungkan informasi yang diketahui dari soal serta menggabungkan prosedur matematika yang diketahui yaitu menggunakan metode substitusi untuk mencari kelompok mana yang menang. Selain itu, $\mathrm{S}$ juga melakukan penyelesaian masalah non routine dengan menggunakan strategi penyelesaian yang tepat. Selanjutnya, S melakukan justifikasi dengan memberikan alasan dari strategi yang digunakan.

Untuk pertanyaan nomor 2 ini, S mengaku bingung awalnya, namun $\mathrm{S}$ balik membaca dan memahami kedua persamaan di atas kemudian bisa menjawab. Untuk poin a., S menggunakan cara dengan mencari KPK dari kedua hewan. Berdasarkan kedua persamaan yang telah diketahui nilai untuk masing-masing hewan, gajah nilainya 28 sedangkan keledai nilainya 5 , sehingga ketemu KPK nya 140, maka ketemu untuk gajah 140:28=5 dan untuk keledai 140:5=28. S menjelaskan bahwa gajah 5 dan keledai 28 merupakan banyaknya hewan, jadi agar permainan berakhir seimbang maka harus ada 5 gajah yang melawan 28 keledai. Peneliti mencoba menggali lebih dalam keterampilan penalaran S dengan menanyakan apakah hanya 5 gajah melawan 28 keledai yang dapat menyebabkan permainan berakhir seimbang?, dan ternyata S menjawab tidak. S mengatakan kalau ada lagi jumlah gajah dan keladai agar permainan seimbang, yaitu 10 gajah $=56$ keladai, 15 gajah $=84$ keledai, 20 gajah $=112$ keledai dan seterusnya dimana gajah kelipatan 5, sedangkan keledai kelipatan 28. Sehingga untuk $\mathrm{n}$ gajah maka $(\mathrm{n} .5)$ gajah $=$ (n.28) keledai. Dalam hal ini S melakukan analisis dengan menuliskan perhitungan dengan benar serta mendeduksi hasil yang benar berdasarkan informasi yang ada pada soal nomor 1. Selain itu, S juga melakukan generalisasi dengan membuat dugaan penyelesaian. Sebagaimana kutipan wawancara S berikut:

$\mathrm{P}$ : pertanyaan nomor 2 a.bagaimana penjelasan dari jawabanmu?

$\mathrm{S}$ : agar permainan berakhir sama kuat maka gajahnya 5 dan keledainya 28, jadi nanti totalnya masing-masing 140.

$\mathrm{P}$ : kok bisa gajah 5 dan keledai 28 ? Bagaimana caramu memperoleh?

S : saya cari KPK nya bu. Karena 1 gajah nilainya 28, sedangkan 1 keledai nilainya 5 jadi KPK nya 140, lalu saya bagi, $140 ; 28=5$ maka banyaknya gajah 5 sedangkan $140: 5=28$ maka banyaknya keledai=28

P : kenapa kok 5 gajah harus melawan 28 keledai? Apa cuma itu yang hasilnya seimbang?

$\mathrm{S}$ : ada lagi bu, 10 gajah melawan 56 keledai, nanti jadinya 280.

$\mathrm{P}: 280$ itu apa?

$\mathrm{S}: \mathrm{KPK}$ nya bu, jadi biar seimbang maka dicari KPK nya bu

$P$ : jadi?

$\mathrm{S}$ : jadi yang bisa adalah 5 gajah $=28$ keledai, 10 gajah $=56$ keledai, dan seterusnya kelipatan 5 gajahnya dan kelipatan 28 kedelainya.

$\mathrm{P}$ : emm oke, lalu?

$\mathrm{S}$ : lalu kalau $\mathrm{n}$ gajah berarti (sambil mikir..) 5 gajah $=28$ keledai, 10 gajah $=56$ keledai, 20 gajah $=112$ keledai, jadi kalo $\mathrm{n}$ gajah $=\mathrm{n}$ keledai dimana gajahnya (n.5) karena gajah kelipatan 5 sedangkan keledai (n.28) karena kelipatan 28.

$\mathrm{P}$ : artinya kelipatan 5 dan kelipatan 28 itu apa sih?

$\mathrm{S}$ : maksudnya selain 5, 10,15, 20,.. itu gak bisa seimbang, nanti menang sebelah. Begitu pula untuk keledai, kalo nggak kelipatan 28 dia nggak bisa setara melawan gajah.

$\mathrm{P}$ : ooh jadi misalnya saya mau gajah jumlahnya 1,2,3,4,6,7,8,9 itu tidak bisa?

$\mathrm{S}$ : tidak bisa bu. Karena nanti hasilnya koma-koma, tidak pas, tidak sama dengan.

$\mathrm{P}$ : ooh oke.

Berdasarkan cuplikan wawancara di atas, S melakukan analisis dengan menjelaskan informasi yang diketahui, menuliskan model matematika namun tidak dalam bentuk variabel. Selanjutnya, S melakukan sintesis dengan menghubungkan hasil dari soal nomor 1. Selain itu, S melakukan generalisasi dengan membuat pola yang terbentuk. S juga melakukan justifikasi dengan memberikan alasan yang meyakinkan dari jawabannya. Terakhir $\mathrm{S}$ juga melakukan pemecahan masalah non-routine dengan menggunakan strategi penyelesaian yang tepat.

Untuk soal nomor 2.b, S lebih cepat menjawab karena telah berhasil menemukan pola dari soal 2.a. S mencoba mencari nilai dari keledai dibawah nilai seekor gajah yang nilainya 28, yaitu ketemu lima ekor keledai, karena nilai dari seekor keledai adalah 5, berdasarkan persamaan pertama, kemudian disubstitusi untuk 5 ekor keledai ketemu 25. S menjelaskan bahwa 1, 2, 3, 4, 5 merupakan jumlah keledai yangmana jika melawan seekor gajah akan dimenangkan gajah. Karena pertanyaannya berapa 
paling banyak keledai, maka diambillah lima ekor keledai. Selanjutnya peneliti menggali penalaran $\mathrm{S}$ lebih dalam dengan menanyakan untuk $n$ gajah bagaimana?, S menjawab dengan enteng kalo jawabannya tinggal ditambahin $\mathrm{n}$. Ketika ditanya maksudnya gimana, S menjawab bahwasanya untuk melawan gajah, gajahnya berjumlah $\mathrm{n}$, dan harus menang gajah maka dibutuhkan 5n keledai, dimana nilai dari n gajah dan n keledai harus sama. Dalam hal ini S melakukan generalisasi dengan membuat pola matematika. Hal ini sebagaimana dikutip dalam wawancara berikut:

$\mathrm{P}$ : soal nomor $2 . \mathrm{b}$ ?

$\mathrm{S}$ : untuk 2.b, agar gajah menang maka dibutuhkan 5 keledai.

$\mathrm{P}$ : kenapa kok dibutuhkan 5 keledai? Apa alasannya?

$\mathrm{S}$ : karena 1 keledai nilainya 5 dan $5 \times 5=25$ sedangkan 1 gajah kan 28 bu.

P : kenapa harus 5? Apakah 4 tidak bisa? Kan 4 juga hasilnya dibawah 28. Atau 3 misalnya, kenapa?

$\mathrm{S}$ : karena yang ditanya paling banyak keladai bu, sebenernya 1, 2, 3, 4, 5 keledai itu sama-sama menang gajahnya, tapi kan yang ditanya paling banyak keledai makanya ya 5 bu jawabannya.

$P$ : okee, jadi?

$\mathrm{S}$ : jadi untuk melawan 1 gajah dan agar gajahnya menang, maka dibutuhkan 5 keledai.

$\mathrm{P}$ : bagaimana itu maksudnya?

$\mathrm{S}$ : karena pertanyaanya untuk n gajah, berarti untuk melawan n gajah dan agar gajahnya menang maka dibutuhkan 5n keledai

$\mathrm{P}:$ n nya berapa?

$\mathrm{S}$ : ya berapapun bu, pokoknya n nya keledai dan gajah kudu sama.

Dari hasil wawancara di atas, terlihat bahwa $\mathrm{S}$ melakukan analisis dengan melakukan perhitungan yang tepat. S juga melakukan sintesis dengan menggabungkan prosedur yang dimiliki untuk mencari hasil yang seimbang. S juga melakukan generalisasi dengan membuat pola yang terbentuk. Selanjutnya, S melakukan justifikasi dengan memberikan alasan dari jawaban serta melakukan penyelesaian masalah non-routine dengan menggunakan strategi penyelesaian yang tepat.

Untuk soal nomor 2.c, S lebih cepat menjawab. S menjelaskan runtut sebagaimana ia menjawab soal nomor $2 . b$. $S$ memulai dengan mencari nilai keledai diatas nilai seekor gajah agar gajahnya kalah, dan ketemu keledai 30 melawan gajah 28 , ternyata banyaknya keledai agar nilainya 30 adalah sebanyak enam keledai, dan banyak gajahnya satu ekor. Selanjutnya untuk n gajah maka dibutuhkan 6n keledai agar permainan berakhir gajahnya kalah. Dalam hal ini $\mathrm{S}$ melakukan generalisasi. Sebagaimana kutipan wawancara dibawah:

$\mathrm{P}$ : soal nomor 2.c

$\mathrm{S}$ : sama kayak 2.b bu

$\mathrm{P}$ : bagaimana penjelasannya?

S : kan kalo yang c ini agar gajah kalah, maka dibutuhkan 6 keledai. Karena 1 gajah beratnya 28, sedangkan satu keledai beratnya 5 maka $6 \times 5=30$ maka gajahnya pasti kalah. Karena yang ditanyakan untuk n gajah, maka keledainya pun jadi 6n keledai.

$P$ : jadi?

$\mathrm{S}:$ jadi untuk n gajah akan kalah melawan 6n keledai.

Dari hasil wawancara di atas, terlihat bahwa $\mathrm{S}$ melakukan analisis dengan melakukan perhitungan yang tepat. $\mathrm{S}$ juga melakukan sintesis dengan menggabungkan prosedur yang dimiliki untuk mencari hasil yang seimbang. S juga melakukan generalisasi dengan membuat polayang terbentuk. Selanjutnya, S melakukan justifikasi dengan memberikan alasan dari jawaban serta melakukan penyelesaian masalah non-routine dengan menggunakan strategi penyelesaian yang tepat

\section{PEMBAHASAN}

Tujuan dari penelitian ini adalah untuk mendeskripsikan proses penalaran siswa SMA dalam menyelesaikan soal nonroutine. Indikator dalam penelitian ini mengadopsi dari TIMSS (Gunham, 2014) yang mencakup beberapa komponen yaitu analisis, sintesis/integrasi, generalisasi, justifikasi, dan penyelesaian masalah non-routine. Subjek yang dipilih dalam penelitian ini merupakan siswa yang memiliki tingkat kemampuan matematika tinggi berdasarkan rekomendasi guru pengampu mata pelajaran serta hasil capaian belajar. Subjek juga dipilih berdasarkan hasil jawaban dari soal test serta hasil wawancara yang memenuhi kelima indikator penalaran. Sebagaimana pendapat dari Hidayati \& Widodo (2015) bahwasanya siswa yang memiliki kemampuan matematika tinggi menunjukkan aktivitas penalaran matematisnya pada setiap proses pemecahan masalah, sedangkan siswa yang mempunyai kemampuan matematika sedang dan rendah, ada beberapa proses pemecahan masalah yang tidak menunjukkan keterampilan penalaran.

Pada bagian mencari persamaan pertama, subjek penelitian menjelaskan informasi apa saja yang dia ketahui setelah membaca pernyataan di alenia pertama. Dari jawaban subjek ini, terlihat bahwa subjek telah memakai indikator analisis. Setelah itu subjek menggunakan pengetahuan yang dimilikinya untuk menjawab nilai dari persamaan, dimana dalam hal ini subjek menggunakan cara mencari KPKnya. Dari pernyataan ini, subjek telah melakukan indikator pemecahan masalah non-routine. Pada bagian mencari nilai masing-masing hewan pada persamaan pertama ini, subjek juga memberikan alasan/argumen dalam 
setiap jawabannya, sehingga subjek telah menggunakan indikator justifikasi. Pada bagian mencari persamaan kedua, subjek penelitian menggunakan metode substitusi yaitu mengganti hewan dengan nilai yang sudah dia ketahui pada persamaan pertama. Dalam hal ini subjek telah melakukan sintesis dan pemecahan masalah non-routine. Selanjutnya subjek menemukan nilai dari gajah setelah perhitungan pada kelompok lawan permainan. Jawaban ini menunjukkan bahwa subjek telah melakukan indikator analisis. Pada bagian mencari persamaan kedua, subjek juga memberikan argumen dari jawabannya, artinya subjek telah melakukan justifikasi.

Untuk soal pada poin 1, subjek penelitian menuliskan model matematika, namun masih dalam bentuk hewan. Subjek sengaja tidak merubah atau memisalkan nama hewan ke dalam bentuk variabel karena biasanya kalau mengerjakan dia lebih mudah menuliskan apa yang ada di soal, sebagaimana pada kasus ini subjek tetap menuliskan nama hewannya. Dalam hal ini subjek juga telah menggunakan indikator analisis meskipun ada beberapa sub indikator yang tidak digunakan. Selanjutnya subjek melakukan perhitungan dengan metode substitusi nilai masing-masing hewan berdasarkan persamaan pertama dan hasil yang diperoleh dari persamaan kedua. Penjelasan subjek ini menandakan bahwa subjek telah menggunakan indikator analisis, sintesis, dan pemecahan masalah non-routine. Subjek juga memberikan alasan yang rinci terhadap jawaban yang diperoleh untuk soal nomor 1 sehingga subjek telah menggunakan indikator justifikasi.

Untuk soal pada poin 2.a, subjek penelitian melakukan dugaan penyelesaian dengan menulis untuk suku pertama, suku kedua, suku ketiga dan seterusnya sampai ditemukan suku ke-n. Pada jawaban ini subjek telah menggunakan indikator generalisasi. Subjek juga mensubstitusi nilai per satu ekor hewan yang ditanyakan serta memberikan alasan mengapa dia menjawab demikian. Dalam hal ini subjek telah memakai indikator justifikasi dan pemecahan masalah non-routine.

Untuk soal paa poin 2.b dan 2.c, subjek penelitian juga menggunakan indikator generalisasi dengan menyebutkan nilai dari $n$ hewan yang ditanyakan. Subjek mengidentifikasi pola yang terbentuk dengan membuat dugaan penyelesaian. Subjek juga mensubstitusi nilai masing-masing hewan berdasarkan informasi dari persamaan pertama dan kedua serta hasil yang didapat dai soal pada poin 1. Hal ini menunjukkan bahwa subjek telah melakukan indikator analisis, sintesis, justifikasi, dan pemecahan masalah non-routine.

Dalam proses wawancara, subjek juga banyak menggunakan indikator analisis. Sebagaimana dikatakan oleh Kalukar (2014), Siskawati (2014) dan Gunham (2014) bahwa analisis merupakan indikator penalaran yang harus dilakukan siswa dalam menyelesaikan permasalahan. Selain analisis, Wardhani (2008) menyatakan dalam peraturan Dirjen Dikdasmen No. 506/C/Keo/PP/2004 menyatakan bahwa indikator siswa mempunyai keterampilan penalaran adalah memberikan alasan /argumen serta bukti terhadap kebenaran solusi, indikator yang dimaksud adalah justifikasi. Menurut TIMSS (2011) indikator siswa dikatakan melakukan keterampilan penalaran adalah menggabungkan atau mengombinasikan hasil untuk mendapatkan solusi yang lebih baik, dalam hal ini adalah indikator sintesis/integrasi. Stylianides (2008) menyatakan bahwa salah satu indikator penalaran yaitu membuat generalisasi matematis. NCTM (2000) menambahkan salah satu indikator penalaran yang sering digunakan, yaitu memanipulasi aljabar atau memilih strategi penyelesaian yang tepat.

\section{SIMPULAN}

Berdasarkan pembahasan yang telah dijabarkan, dapat disimpulkan bahwa penalaran subjek dalam menyelesaikan soal non-routine sudah memenuhi kelima indikator yaitu analisis, sintesis/integrasi, generalisasi, justifikasi dan penyelesaian masalah non-routine. Subjek memunculkan semua indikator penalaran tersebut dalam menjawab soal namun tidak semua sub indikator digunakan. Berikut merupakan deskripsi penalaran subjek dalam menyelesaikan soal non-routine: untuk aspek analisis, subjek melakukan analisis dengan menjelaskan informasi yang diketahui serta menjelaskan ide-ide matematika baik dalam mencari persamaan maupun dalam menjawab semua soal, subjek juga melakukan perhitungan dengan benar serta mendeduksi hasil dari informasi yang diketahui. Untuk aspek sintesis, subjek melakukan sintesis dengan menggabungkan pengetahuan matematika dan informasi pada kedua persamaan; untuk aspek generalisasi, subjek melakukan generalisasi dengan cara mengidentifikasi bentuk matematika serta membuat dugaan rumus matematika; Untuk aspek justifikasi, subjek melakukan justifikasi dengan memberikan penjelasan dan alasan dari jawaban meskipun hanya sebatas alasan yang terlihat pada jawaban, dalam hal ini subjek belum memberikan alasan yang lebih bermakna artinya dari segi pemaknaan konstekstual belum terpenuhi. Untuk aspek pemecahan masalah non-routine, subjek melakukan pemecahan masalah non-routine dengan menggunakan strategi penyelesaian dan menyelesaiakn masalah dengan prosedur yang benar serta menggunakan pengetahuan matematika yang dimiliki sebelumnya untuk menjawab soal.

Berdasarkan pembahasan penelitian dan simpulan penelitian maka saran yang diajukan peneliti yaitu hendaknya siswa dibiasakan untuk bertanya mengapa agar dapat melatih kemampuan justifikasi yang lebih bermakna dalam keterampilan penalarannya sehingga proses pemahaman siswa lebih baik utamanya terkait pemahaman kontekstual, serta dalam penelitian ini subjek melakukan kesalahan dalam mendeskripsikan makna dari nilai sehingga hendaknya dalam pengajaran konsep lebih ditekankan agar siswa lebih paham dalam memaknai. 


\section{DAFTAR RUJUKAN}

Adegoke, B. A. (2013). Modelling the Relationship between Mathematical Reasoning Ability and Mathematics Attainment. Journal of Education and Practice, 4, 1-9.

Bergqvist, T., Lithner, J., \& Sumpter, L. (2008). Upper Secondary Students' Task Reasoning. International Journal of Mathematical Education in Science and Technology, 39(1), 1-12.

Carlson, M. P., \& Bloom, I. (2005). The Cyclic Nature of Problem Solving: An Emergent Multidimensional Problem-Solving Framework. Educational Studies in Mathematics, 58, 45-75.

Elia, I., Panhuizen, M., \& Kolovou, A. (2009). Exploring Strategy Use and Strategy Flexibility in Non-Routine Problem Solving By Primary School High Achievers In Mathematics. ZDM, 41(5), 605-618.

Gunhan, B. C. (2014). A Case Study on The Investigation of Reasoning Skills in Geometry. South African Journal of Education, 34, 19.

Hidayati, A., \& Widodo, S. (2015). Proses Penalaran Matematis Siswa dalam Memecahkan Masalah Matematika pada Materi Pokok Dimensi Tiga Berdasarkan Kemampuan Siswa di SMA Negeri 5 Kediri. Jurnal Math Educator Nusantara, 01(02), 131-143.

Kalukar, E. (2014). Profil Penalaran Siswa SMA dalam Memecahkan Masalah Matematika Dilihat dari Perbedaan Gaya Kognitif Filed Indipendent dan Field Dependent. Tesis tidak diterbitkan. Universitas Negeri Surabaya, Surabaya.

Lee, C.Y., \& Chen, M. P. (2009). A Computer Game as a Context for Non-Routine Mathematical Problem Solving: The Effects of Type of Question Prompt and Level of Prior Knowledge. Computers \& Education, 52(3), 530-542.

Lithner, J. (2012). Learning Mathematics by Creative or Imitative Reasoning. International Congress on Mathematical Education (ICME), 12, 18.

Mullis, I. V. S. (Ed.). (2012). TIMSS 2011. International Results in Mathematics. Chestnut Hill, Mass: TIMSS \& PIRLS Internat. Study Center.

NCTM. (2000). Principles and Standards for School Mathematics. Reston: The National Council of Teachers of Mathematics, Inc.

Pantziara, M., Gagatsis, A., \& Elia, I. (2009). Using Diagrams as Tools for the Solution of Non-Routine Mathematical Problems. Educational Studies in Mathematics, 72(1), 39-60.

Rizta, A., Zulkardi, \& Hartono, Y. (2013). Pengembangan Soal Penalaran Model TIMSS Matematika SMP. Jurnal Penelitian an Evaluasi Pendidikan, 2, 230-240.

Siskawati, F. (2014). Penalaran Siswa SMP dalam Memecahkan Masalah Matematika Ditinjau dari Perbedaan Kepribadian Extrovert dan Introvert. Tesis tidak diterbitkan. Universitas Negeri Surabaya, Surabaya.

Stylianides, G. J. (2008). An Analytic Framework of Reasoning. FLM Publishing Association, 28 (1), 9-16.

Wardhani, D. A. (2016). Penalaran Analogi Siswa Kelas VIII SMP dalam Menyelesaikan Masalah Luas dan Keliling Segitiga dan Segiempat. Tesis tidak diterbitkan. Universitas Negeri Malang, Malang. 